RISEC, Volume 53 (2006), No. 4, 491-530

\title{
WALRAS AND PARETO ON THE MEANING OF THE SOLUTION CONCEPT IN GENERAL EQUILIBRIUM THEORY
}

by

FRANCO DONZELLI*

\begin{abstract}
The notion of solution plays a crucial role in the conceptual system of Léon Walras, the founder of the General Equilibrium Theory (GET). In this paper, after introducing the two solution concepts employed by Walras in the development of his version of GET, respectively called the "theoretical" and the "practical" solution, we discuss the problems such peculiar conception gives rise to, as well as the attempts Walras makes to dodge them. Then we explain why and to what extent Pareto, Walras' immediate successor and co-founder of GET, departs from Walras' original conception, progressively developing an independent viewpoint on the issue of equilibrium computability in GET. (JEL: B13, B21, B31, B41, C62, C68, D50)
\end{abstract}

Keywords: solution, tâtonnement, equilibrium computability

\section{Introduction}

The notion of solution plays a crucial role in the conceptual system of Léon Walras, the founder of General Equilibrium Theory (henceforth, GET). In this paper we want to discuss the twofold meaning attached to this notion by Walras, the problems such peculiar conception gives rise to, as well as the attempts Walras makes to dodge them. After that, we intend to explain why and to what extent Vilfredo Pareto, Walras's immediate successor and cofounder of GET, departs from the Walrasian conception, eventually developing an interpretation of GET where the issue of the solvability of

\footnotetext{
* Department of Economics, Business and Statistics, University of Milano, Milan (Italy). Email: franco.donzelli@unimi.it
} 
general equilibrium models is viewed in a way which significantly differs from that originally suggested by Walras.

The paper is structured as follows. Section 2 discusses Walras's perspective: precisely, in subsection 2.1 we introduce the distinction between the two solution concepts employed by Walras in the development of his version of GET, called the "theoretical" and the "practical" solution, respectively; subsection 2.2 analyzes the "theoretical" solution, while subsection 2.3 examines the "practical" one. Section 3 focuses instead on Pareto's perspective: precisely, subsection 3.1 analyzes Pareto's attitude towards Walras's interpretation of the solution concept in GET; subsection 3.2 examines the evolution of Pareto's ideas about equilibrium computability in GET; finally, subsection 3.3 discusses the influence exerted by Pareto's mature position on the computability issue on some later conceptions, such as Hayek's, of the ultimate significance of GET. Section 4 concludes.

\section{Walras's Perspective}

Walras's reflections on the meaning and use of the solution concept in general equilibrium models are spread all over his scientific production, starting from the four mémoires separately written and published by Walras in the period 1874-1877 (Walras 1874, 1876a, 1876b, 1877). The draft of these mémoires is strictly intertwined with that of the first edition of the Eléments d'économie politique pure, Walras's fundamental theoretical work, published in two installments in the same period. During Walras's lifetime three further editions of the Eléments were sent to press, in 1889 (II edition), 1896 (III edition), and 1900 (IV edition), respectively ${ }^{1}$.

In all the above quoted writings, and especially in the Eléments, Walras develops his theoretical system through a sequence of stages, by means of a peculiar constructive and expository method that will partly survive in the subsequent evolution of GET. Walras's method consists in elaborating a sequence of nested models, arranged in order of increasing scope: the models are nested in the sense that the descriptive power of each model is larger than that of its predecessor in the sequence (provided that such a predecessor

\footnotetext{
${ }^{1}$ Since 1988 a critical variorum edition of the Eléments is available, which allows the scholar to easily compare the text of the various editions; in the following, therefore, we shall always refer to this edition, contained in vol. VIII of the Euvres économiques complètes d'Auguste et de Léon Walras. When quoting from the critical variorum edition we shall adopt the following convention: Walras (1988, page number(s) of the critical edition, number(s) of the original edition(s) in bold); if the text remains unaltered in all the editions, no edition number is specified.
} 
exists); from a phenomenical point of view, therefore, each model contains the preceding one and is contained in the following (provided that such predecessor and/or successor exist). Three models are fully developed in the four mémoires as well as in all the editions of the Eléments: they are the socalled models of exchange, production, and capital formation ${ }^{2}$. In the fourth edition, however, Walras explicitly puts forward a fourth model which, beyond dealing with the issues already discussed in the third, tackles the questions of circulating capital and money as well.

2.1. Walras's twofold solution concept. - According to Walras, the economic theorist, after formalizing a given problem by means of a suitable mathematical model, ought to complete his task by both explaining how the model concerned can be "solved" and identifying the correspondent "solution". Specifically, referring to the formal models of which his version of GET consists, Walras makes it clear that, in order to solve each model, one needs to resort to a special two-stage procedure, each stage being associated to a particular solution concept. The following passage clearly illustrates Walras's position in this respect:

Or, pour démontrer que des prix de marchandises, qui sont des quantités, [...] résultent effectivement de telles ou telles données ou conditions, il est absolument indispensable à mon sens: $1^{\circ}$ de formuler, d'après ces données ou conditions, un système d'équations, en nombre rigoureusement égal à celui des inconnues, dont les quantités en question soient les racines, et $2^{\circ}$ d'établir que l'enchaînement des phénomènes de la réalité constitue bien la résolution empirique de ce système d'équations. C'est ce que j'ai fait en ce qui concernait successivement l'échange, la production et la capitalisation. ${ }^{3}$

As can be seen, to solve a model in Walras's sense means to take two sequential steps: the first leads to a solution concept which is referred to by Walras as either the "theoretical" or the "mathematical" or even the

\footnotetext{
${ }^{2}$ As a matter of fact, there exist two nested versions of the model of exchange: the first one, which plays a merely propedeutical role, deals with a pure-exchange, two-commodity economy with an arbitrary finite number of traders; the second generalizes the findings of the first to a pure-exchange economy with an arbitrary finite number of commodities and traders.

${ }^{3}$ Walras (1988, p. 651). At the end of the quoted passage only the first three models put forward by Walras in the Eléments and related writings (namely, the models of exchange, production, and capital formation) are listed, while the fourth model, extending Walras's analysis to circulating capital and money, is omitted. This omission is simply due to the fact that the quoted passage, dating back to the first edition of the Eléments, remains unchanged in all the subsequent editions, including the fourth one; hence, the drafting of such passage can be traced back to a time when the issues concerning money had not yet become the subject-matter of a formal model, to which Walras's characteristic two-stage solution procedure could apply.
} 
"scientific" solution; the second one, instead, leads to another sort of solution concept, which is labelled by him as either the "practical" or the "empirical" solution (Walras, 1988, pp. 93, 307, 375; 1988, p. 189, 2-4; 1988, p. 461, 4). Henceforth, to simplify the exposition, we shall make use of only one qualifier to designate either kind of notion: hence, in the sequel, the first solution concept will be qualified as the "theoretical" one, while the second will be referred to as the "practical" one. Let us now consider the two notions in turn, starting from the "theoretical" one, which, in Walras's theoretical system, precedes the "practical" one from both an expositional and a logical point of view.

2.2. The "theoretical" solution. - According to Walras, given an economic problem, identified by a set of distinctive "data", "conditions" and "unknowns", the first thing the theorist has to do is to construct a formal model of the problem concerned by specifying a "system of equations" which suitably incorporates the "data" and the "conditions" (parameters, functions, relations), as well as the "unknowns" of the problem at issue; besides that, the theorist has to make sure that the number of the independent equations be "rigorously equal to that of the unknowns" to be determined. In accordance with his general stance, for each of his four equilibrium models Walras takes care of formulating a system of ordinary algebraic equations, checking in each case that the number of the unknowns be the same as that of the independent equations of the model. The "theoretical" solution, then, is nothing other than the mathematical solution of the system of equations describing the problem under question. To any such solution one can associate certain specified values of all the unknown variables, which can then be viewed as describing an "equilibrium" of the model itself.

When the notion of "theoretical" solution is so interpreted, two distinct questions naturally arise: Is the "theoretical" solution determinate? Is it concretely computable by the theorist? The first question, in turn, naturally subdivides into two distinct sub-questions: Does a "theoretical" solution exist? Is it unique? Hence, in the end, with regard to the "theoretical" solution of a model in Walras's sense, three distinct issues can be easily identified that ought to be confronted by the theorist: the first has to do with the existence, the second with the uniqueness, and the third with the computability of a "theoretical" solution. Walras discusses at length all the three issues. None of the answers he tentatively puts forward, however, would satisfy the contemporary standards of rigor.

As far as the existence issue is concerned, Walras's insistence on the equation-counting criterion might easily lead the reader to believe that the 
required equality between the number of the independent equations and the number of the unknowns to be determined does indeed represent for Walras a sufficient condition for the existence of a solution of the system of equations that, in his view, necessarily provides the formal structure of any given equilibrium model. Yet the situation is more complicated than it might appear at first sight: for, while the equation-counting criterion is certainly not sufficient for justifying any claim as to the existence of a solution, as simple mathematical reasoning would easily confirm, it is by no means clear whether or not Walras consistently holds the opposite view. In fact, there are a few passages in his writings where his supposed faith in the power of that criterion seems to waver.

In particular, in analyzing from a geometrical point of view the question of the existence of solutions in the simple model of a pure-exchange, twocommodity economy, Walras arrives at the conclusion that, under certain $a$ priori acceptable assumptions concerning the characteristics of the traders and the shapes of the excess demand curves, "[i]l n'y aurait pas de solution" (Walras, 1988, p. 96-97). This conclusion, however, is somewhat paradoxical, since it concedes more than is actually implied by the example concerned. In fact, what Walras is supposing in his illustration is that the maximum price (say, $\bar{p}^{s} \geq 0$ ) at which the assumedly non-decreasing aggregate direct supply function of either commodity is nil be greater than the minimum price (say, $\underline{p}^{d} \geq 0$ ) at which the assumedly non-increasing aggregate direct demand function for the same commodity is nil. However, from these assumptions it would simply follow that the aggregate excess demand function for the commodity concerned is nil for the whole continuum of prices belonging to the interval $\left[\underline{p}^{d}, \bar{p}^{s}\right]$. From a formal point of view, therefore, the phenomenon that Walras is actually discussing has nothing to do with the possible inexistence of solutions, in the modern sense of that expression; rather, what he actually describes is a no-trade equilibrium which, while perfectly legitimate from a contemporary point of view, would however be associated with a continuum of equilibrium prices. Contrary to Walras's suggestion, therefore, in the case under discussion the issue at stake would not concern the existence, but rather the uniqueness of the solution.

Let us turn, then, to the uniqueness question. In this respect, at the very beginning of his theoretical construction, and referring once again to the simple model of a pure-exchange, two-commodity economy, Walras explicitly allows for the possible existence of multiple solutions or equilibria of the model (Walras, 1988, pp. 97-100). Having granted this possibility, however, he tends to confine it to the elementary case of the exchange of two 
commodities for one another, belittling the probability of its occurrence in more complex situations, such as the case of the exchange of many commodities for each other (Walras, 1988, pp. 99-100, 242). Moreover, even when the possibility of multiple solutions is allowed for, their number is always assumed to be finite, so that the solutions are locally unique ${ }^{4}$.

To sum up on the determinateness of the "theoretical" solution, we can conclude that Walras's position on this issue is not free of ambiguities or mistakes: he does not clearly distinguish between the existence and the uniqueness questions; he is ready to admit the inexistence of a solution precisely when a whole continuum of solutions exists; on the contrary, he repeatedly stresses the relevance of the equation-counting criterion, as if the latter could provide a definite answer to the existence issue and even to the uniqueness one; finally, while admitting the possibility of multiple solutions in the simplest of his models, he then makes that problem substantially disappear in the rest of his analysis without much (or any) justification.

Of course, it would be unfair to judge Walras's successes and failures in the light of the subsequent developments of GET. This remark particularly applies to the issues of equilibrium existence and uniqueness, which have experienced such an extraordinary progress since the mid-1930s as to make any comparison between the present state of the art and that prevailing in Walras's times almost irrelevant. All the same, a moderate resort to hindsight can still allow the interpreter to reap some benefits: for, by looking at the successful approaches to the existence and uniqueness issues that have been devised and implemented over the last seventy years or so, one can also hope to shed some light on the reasons why Walras's original attempts at addressing the same questions were not crowned with success.

The first lesson one can draw from the debate of the mid-1930s on the existence of an equilibrium in models of Walrasian derivation, as reconstructed, e.g., by Weintraub (1983), is that the existence issue cannot be successfully dealt with until the search for an equilibrium is not clearly distinguished from the search for a solution of a system of equations. Walras had occasionally contemplated the possibility that inequalities, instead of equations, might be associated with an equilibrium state: in particular, from the second edition of the Eléments onwards, he had acknowledged that an equilibrium of his capital formation model might require that some of the equations originally (i.e., in the first edition) employed to define the

\footnotetext{
${ }^{4}$ As we have seen above, however, there is at least one passage in the Eléments which is consistent with the existence of what a modern theorist would interpret as a continuum of equilibrium prices. But, as already explained, the equilibrium nature of such prices is not acknowledged by Walras.
} 
equilibrium conditions of that model should be turned into inequalities (Walras, 1988, p. 401, 2-4). This occasional recognition, however, had not been enough to convince him to call in question his reiterated identification of the equilibrium of a model with the "theoretical" solution of the equation system supposedly defining it.

In fact, it is only during the debate of the mid-1930s that general equilibrium theorists start to accept the idea that the very concept of general competitive equilibrium needs to be redefined in such a way as to allow for the possibility that some equilibrium conditions be satisfied as strict inequalities, possibly associated with suitable complementary slackness conditions; so that, during that debate, Walras's formal identification of the equilibrium concept with the concept of solution of an equation system is eventually abandoned. Such change in perspective, in turn, proves to be an important step towards a general solution of the existence issue: for, as soon as it is acknowledged that an equilibrium may be something different from the solution of an equation system, the way is paved for the exploration of methods of proving the existence of an equilibrium which are different from the traditional, inevitably unsuccessful, attempts of directly proving the existence of solutions of hopelessly unmanageable systems of equations. As is well-known, this quest will eventually lead to the employment of fixedpoint theorems in the equilibrium existence proofs. But, since we are aware nowadays that fixed-point theorems and equilibrium existence theorems in GET are essentially equivalent ${ }^{5}$, we also know that there is no other general way to prove the existence of an equilibrium in general equilibrium models than to rely on fixed-point theorems of some sort. Hence, since no such theorem was known in Walras's times, this would be enough by itself to explain why his attempts at confronting the existence and uniqueness issues were necessarily doomed to failure.

Something similar applies also to the third question concerning the "theoretical" solution in Walras's sense: for, in view of the recalled equivalence between fixed-point theorems and equilibrium existence theorems in GET, one cannot but agree with Scarf (1982, p. 1015) that "any effective numerical procedure for computing equilibrium prices must at the same time be an algorithm for computing fixed points of a continuous mapping". So, also with respect to the third question, we might conclude that, due to the lack of the necessary mathematical knowledge and skills, it would have been literally impossible for Walras to concretely compute the equilibrium values corresponding, in his view, to the "theoretical" solution of

\footnotetext{
${ }^{5}$ See, e.g., Uzawa (1962).
} 
any one of his equilibrium models. But, concerning computability, there is another issue that should be preliminarily discussed: for, given a certain model and an associated equation system, it is not even clear whether or not Walras really trusted the theorist formulating or analyzing such model to be actually capable to compute the "theoretical" solution, assumed to exist and be unique, of the equation system concerned.

In this respect, over a time span of a few months, Walras takes two seemingly conflicting positions. For, in his first significant theoretical writing, the mémoire on the elementary theory of exchange published in January 1874 , referring in particular to the simple problem of the exchange of two commodities for one another, he writes:

A priori, ce problème est évidemment soluble, du moins en principe, par le procédé mathématique, comme il est soluble, en fait, sur le marché, par le procédé empirique de la hausse et de la baisse. Sur notre marché, nous avons supposé les acheteurs et les vendeurs en présence les uns des autres; mais la présence des ces échangeurs n'est pas nécessaire: qu'ils donnent leurs ordres à des agents, le marché ce tiendra entre ces derniers. [...] Mais, théoriquement, la présence des agents est-elle plus nécessaire que celle des échangeurs euxmêmes? Pas le moins du monde. Ces agents sont les exécuteurs purs et simples d'ordres inscrits sur des carnets: qu'au lieu de faire la criée, ils donnent ces carnets à un calculateur, et ce calculateur déterminera le prix d'équilibre non pas certes aussi rapidement, mais à coup sûr plus rigoureusement que cela ne pourrait se faire par le mécanisme de la hausse et de la baisse. (Walras, 1874, p. 37; italics added)

Yet, on coming back to the same subject in the first installment of the first edition of the Eléments, published just six months later in July 1874, Walras writes:

On voit clairement à présent ce qu'est le mécanisme de la concurrence sur le marché; c'est la solution pratique, et par hausse et baisse des prix, du problème de l'échange dont nous avons fourni la solution théorique et mathématique. On doit comprendre d'ailleurs que notre intention n'est aucunement de substituer une solution à l'autre. La solution pratique est d'une rapidité et d'une sûreté qui ne laissent rien à désirer. On peut voir, sur de grands marchés fonctionnant même sans courtiers ni crieurs, le prix courant d'équilibre se déterminer en quelques minutes, et des quantités considérables de marchandise s'échanger à ce prix en deux ou trois quarts d'heure. Au contraire, la solution théorique serait, dans presque tous les cas, absolument impraticable. (Walras, 1988, p. 93; italics added)

In both passages Walras deals with his simple model of a pure-exchange, two-commodity economy, whose formal structure is represented by one single market-clearing equation with only one unknown variable to be 
determined, namely, the only independent relative price. Moreover, in both passages Walras contrasts the "theoretical" solution of the model with the "practical" one: while to compute the former solution would be the task, whose feasibility has yet to be ascertained, of the theorist who has formulated the model (precisely, of the "calculateur" mentioned in the first passage), to compute the latter is the practical or empirical task, whose feasibility is beyond doubt, of the "mécanisme de la concurrence sur le marché". As to the "theoretical" solution, in the first passage Walras asserts that it is computable, at least in principle, provided that the "calculateur" be given the necessary information, consisting, in the case under discussion, of the knowledge of the individual demand functions; under this assumption, the "calculateur" can determine the equilibrium price less quickly, but more rigorously, than the competitive mechanism. On the contrary, in the second passage, Walras asserts that the "theoretical" solution is absolutely impracticable in almost every case; moreover, even granting that the "theoretical" solution could be computed at all, the "practical" solution provided by the competitive mechanism would be reached not only more quickly, but also more certainly than the "theoretical" one.

That the two passages express contradictory views about the computability of the "theoretical" solution is an undeniable fact. Yet, the apparent conflict can be significantly reduced, if not completely cancelled, if one takes into account the different purposes pursued by Walras in writing the two passages. To see this, let us assume once again, in the wake of Walras, that the "theoretical" solution of the equation system associated with the equilibrium model under discussion exists and is unique. Then, under this assumption, let us ask why it might prove impossible to numerically compute such a solution. Two different reasons stand out for scrutiny: first, the theorist might be unable to obtain the necessary detailed information about the data and the conditions of the model, that is, about the parameters, functions, and relations on which the equation system depends; second, even granting that all the required quantitative information were somehow made available to the theorist, the latter might still be unable to numerically solve the equation system because no efficient algorithm is available which would allow the "calculateur" to actually compute such numerical solution.

Now, in the first passage, Walras is evidently willing to address the computability issue under the provisional assumption, made for discussion's sake, that all the necessary quantitative information, as represented by the individual demand functions, be actually conveyed to the "calculateur",

\footnotetext{
${ }^{6}$ There are many clues suggesting that, in the first passage, the assumption that one single mind or entity can come to possess a complete knowledge of all the relevant data of the model
} 
under this assumption, he is ready to express a moderately optimistic view about the computational skills of the "calculateur" who, in his opinion, would certainly be slower, but in the end more precise than the market in approaching the solution of the equation system describing the model ${ }^{7}$. But what Walras is willing to assume in the first passage, he is no longer prepared to grant in the second: for in the latter, at least in our opinion, Walras betrays his deepest conviction that, in almost all cases, the theorist cannot obtain the necessary quantitative information about the data and conditions of the model; and, in the last analysis, it is this pessimistic belief that explains why, according to Walras, the "theoretical" solution is "absolutely impracticable in almost every case".

Our interpretation of the reasons underlying the negative conclusion about the computability of the "theoretical" solution reached by Walras in the passage drawn from the Eléments, is confirmed by the sentences that immediately follow the passage concerned:

Aussi serait-ce faire une objection bien mal fondée que de nous parler de la

is made just for the sake of the discussion, without any pretence to realism. In the first place, a number of expressions employed by Walras in his exposition (such as "a priori", "en principe", "théoriquement") reveal the purely hypothetical character of the example he is developing. In the second place, the situation described by Walras is itself patently artificial and deliberately unrealistic: in fact, in the case in point, the relevant data consist in the traders' dispositions to trade, as summarized by their demand functions; this information is then supposedly transmitted to the "calculateur" through a sequence of steps which cannot obviously be taken as the description of something real. The steps in the sequence are the following: first the traders are required to write down their dispositions to trade on appropriate block-notes; then they are supposed to hand over their block-notes to agents representing them in the market; finally, the agents are required to hand over such block-notes to the "calculateur". This is really too contrived a procedure to be taken as an idealized description of a real-world situation.

${ }^{7}$ Walras's optimism about the "calculateur"'s computing abilities (that is, about his own and his fellow economists' computing skills), though tempered with caution, is all the same unjustified: for, at least in Walras's times, no economic theorist assumedly possessing all the required information about the data of a moderately complex general equilibrium model would have been able to numerically solve the equation system describing the model concerned, however long the time granted for that computation. Certainly Walras himself would not have been able to accomplish such feat: for the only solution algorithm he indirectly proves to be somehow acquainted with resembles "an iterative method for solving systems of equations which is known as the Gauss-Seidel method in numerical analysis" (Uzawa, 1960, p. 186, fn. 1); but, as Arrow and Hahn (1971, pp. 305-306) do not fail to point out, such an algorithm is not particularly efficient. Moreover, it should be stressed that Walras does not clearly connect his own iterative method for solving equation systems with the computability issue, which is one of the issues related with the so-called "theoretical" solution, but rather, as we shall see in the next subsection (fn. 9), with the question of the empirical discovery of the "practical" solution by the competitive market mechanism. 
difficulté d'établir les courbes d'échange ou leurs équations. L'avantage qu'il pourrait y avoir, dans certains cas, à dresser, en totalité ou en partie, la courbe de demande ou d'offre d'une marchandise déterminée, et la possibilité ou l'impossibilité de le faire, est une question que nous réservons toute entière. Pour le moment, nous étudions le problème de l'échange en général, et la conception pure et simple des courbes d'échange nous est à la fois suffisante et indispensable. (Walras, 1988, p. 93)

Here Walras implicitly reaffirms a fundamental methodological prescription by which mathematical economics ought to abide: namely, he suggests that the purpose of the mathematization of the theory is not so much to allow the theorist to precisely draw curves nor to compute numerical values of the unknown variables, a purpose on the very feasibility of which all judgement should be suspended; rather its purpose is to clarify the conceptual system to be employed by the theorist, thereby making rigorous analysis possible.

In the above statements one can easily find many a trace of Cournot's conception of the role of mathematical analysis in the development of theoretical economics, as expressed, in particular, in the Preface to his 1838 book:

J'ai dit que les auteurs spéciaux dans ces matières semblent d'ailleurs s'être fait une idée fausse de la nature des applications de l'analyse mathématique à la théorie des richesses. On s'est figuré que l'emploi des signes et des formules ne pouvait avoir d'autre but que celui de conduire à des calculs numériques [...]. Mais les personnes versées dans l'analyse mathématique savent qu'elle n'a pas seulement pour objet de calculer des nombres; qu'elle est aussi employée à trouver des relations entre des grandeurs que l'on ne peut évaluer numériquement, entre des fonctions dont la loi n'est pas susceptible de s'exprimer par des symboles algébriques. (Cournot, 1838, pp. VII-VIII)

Though occasionally acknowledging his debt towards Cournot, Walras is always very careful to circumscribe the role played by his predecessor in the development of his own system of thought. For instance, in his first mémoire, after praising Cournot for his path-breaking contribution to the mathematization of economics, Walras immediately adds that "[...] nos recherches ne se confondent point et je crois pouvoir dire que je ne lui ai emprunté que sa méthode", where by method he simply means "l'application des mathématiques à l'économie politique" (Walras, 1874, p. 29; see also 1988, p. 5, 4). Among the many reasons that might explain Walras's minimizing attitude towards Cournot's theoretical contribution, one is perhaps suggested by a remark contained in a letter that the former sends to the latter in March 1874: 
Notre méthode est la même, car la mienne est la vôtre, seulement, vous vous placez immédiatement au bénéfice de la loi des grands nombres et sur le chemin qui mène aux applications numériques. Et moi je demeure en deçà de cette loi sur le terrain des données rigoureuses et de la pure théorie. (Walras in Antonelli, 1935, p. 123)

Here Walras is contrasting his own theoretical orientation towards general, multi-market analysis with Cournot's orientation towards partial, singlemarket analysis, also in view of possible numerical applications; but, almost certainly, he is also critically commenting upon the fact that Cournot, in his Recherches, while refraining from taking the individual data of the exchange problem (that is, individual utility functions and endowments) as the starting point for the construction of market demand functions, occasionally endorses the idea that the "law of demand" might be obtained by means of "empirical" or "statistical" procedures, possibly leading to "numerical applications" (Cournot, 1838, pp. 47-50). The point made by Walras in this letter is interesting, because he makes it clear that, for the purposes of "pure theory", only individual data can be regarded as "rigorous". Moreover, according to Walras, the obvious difficulties encountered by the theorist in collecting and processing such data ought not to be circumvented, as Cournot allegedly suggests, by resorting to statistical procedures aimed at the attainment of numerical results.

In view of these last remarks, our discussion of Walras's overall position towards the computability issue may be summarized as follows: in spite of a few oscillations and possibly misleading statements, Walras keeps substantially faithful to the idea that, due to the individual and dispersed nature of the data characterizing most economic problems, no real knowledge of the data can be obtained in almost every case, so that, for this very reason, the computability question should be answered in the negative.

On the other hand, the recognition that the "theoretical" solution of a given model is almost never computable by the theorist by no means lessens either the role played by the theory or its empirical content. The latter, in particular, is always assured by the fact that, in Walras's view, the concrete determination of the solution, or the effective establishment of the equilibrium of the model under question, is the outcome of the empirical procedure implemented by the competitive market mechanism. In other words, whether the "theoretical" solution is computable or not becomes a question of minor interest, as soon as one is ready to admit that, from a "practical" or "empirical" point of view, it is the market to solve the model or, better, the problem the model describes, by approaching and eventually discovering the so-called "practical" solution. 
2.3. The "practical" solution. - This last remark brings us back to the second requirement that, according to Walras, must be met in order that a model expressed in equational form may be regarded as properly solved. The discussion of both the second requirement and the associated "practical" solution concept permeates all of Walras's theoretical work. Yet, in spite of the relentless efforts Walras devotes to improving this part of his theory, a part which is also quantitatively very relevant, he never succeeds in fully understanding and, a fortiori, adequately formalizing the theoretical implications of his own methodological premises.

Once again, for the sake of simplicity, and following Walras's own lead, let us assume that, for any given equilibrium model, the "theoretical" solution exists and is unique. Then, in order to satisfy Walras's second requirement, the theorist ought to proceed as follows. In the first place he should supplement the system of ordinary algebraic equations describing the equilibrium model under question with a system of functional equations, whose purpose is to reproduce or mimic the adjustment processes by means of which the mechanism of competition empirically solves the problem described by the model concerned. According to Walras, in order to mimic the real-world adjustment processes, the dynamical process governed by the adjoined system of functional equations ought to depend on upward or downward movements of suitably specified state variables, reacting to specified disequilibrium gauges: in the exchange model the state variables are the prices of the traded commodities, reacting to the excess demands prevailing in the corresponding markets; in the production models the state variables are the amounts of the produced commodities, reacting to the profits accruing to the corresponding producers. Of course, in order to achieve the stated goal, two further conditions ought to be satisfied: in the first place, the dynamical process described by the adjoined system of functional equations should converge to a stationary solution, which could then be viewed as the "practical" solution approached by the market; and, in the second place, such stationary solution should coincide with the "theoretical" solution, that is, with the mathematical solution of the system of ordinary equations underlying the equilibrium model concerned.

Walras does not evade the tasks that his own methodological prescriptions impose on his research agenda. In effect, for each of his four equilibrium models, he endeavors first of all to construct a specific system of functional (in point of fact, difference) equations, that he interprets as an idealized representation of the competitive adjustment mechanism which operates "par tâtonnement" (Walras,1988, p. 400, 1; p. 308, 376, 398, 401, 2-3; pp. 189, 388-390, 2-4; pp. 326-328, 379, 387; p. 698, 3-4; p. 309, 399, 441, 463, 465, 
4). The label "tâtonnement", that will later come to be commonly used in the literature to designate both the adjustment mechanism originally devised by Walras and some of its variants or offspring, draws its origin precisely from the expression employed by Walras to allude to the fact that the competitive adjustment mechanism can only proceed by trial and error. With respect to terminological matters, it should also be noted that, while Walras's theory of the competitive adjustment mechanism has certainly to do with what any contemporary mathematical economist would describe as a dynamical system or process, Walras himself never uses the word "dynamics" or "dynamical" to refer to this part of his theoretical system; the reason for this will become clear in a moment. In the second place, and once again for each of his four equilibrium models, Walras tries to show not only that the dynamical process converges to a stationary solution, interpreted as the "practical" solution empirically arrived at by the market, but also that such "practical" solution invariably coincides with the "theoretical" one (Walras, 1988, pp. 93, 307, 375 ; p. $189,2-4 ;$ p. 461,4$)^{8}$.

However, as far as the dynamical part of his theory (in the modern sense of the word) is concerned, Walras's mathematical skills prove to be even poorer than those he had displayed in both the construction of his equilibrium models and the examination of the associated systems of ordinary equations. In effect, in none of his many separate discussions of the tâtonnement construct, one for each equilibrium model, Walras succeeds in formalizing the adjustment process by means of a reasonably complete and formally acceptable system of difference equations; a fortiori, he never really succeeds in proving that the dynamic process does actually converge to a stationary solution'. On the basis of a few heuristic attempts at proving convergence, in

\footnotetext{
${ }^{8}$ A detailed examination of the relations existing between equilibrium and tâtonnement in Walras's theoretical writings, and especially in the Eléments, can be found in Donzelli (2005).

${ }^{9}$ Walras is intimately convinced that, in the real-world markets of a multi-commodity economy, the actual functioning of the mechanism of competition entails a simultaneous adjustment of all the relevant state variables: e.g,, if a real-world exchange economy were out of equilibrium, the competitive market mechanism would cause, according to Walras, a simultaneous change in the prices of all the traded commodities in the appropriate directions. The formalization of such a "simultaneous" tâtonnement process, however, would require the use of mathematical methods, based on vector analysis and multivariate calculus, which are well beyond Walras's capabilities. Essentially for this reason Walras is unwillingly forced to contrive a market-by-market adjustment process, where the state variables are sequentially adjusted one at a time; though admittedly unrealistic, such a "successive" tâtonnement process is preferred by Walras to the "simultaneous" one, since, unlike the latter, it can at least be described, though certainly not solved, by means of scalar methods not unfamiliar to him (see Walras's letter to the Italian economist Maffeo Pantaleoni, dated September 2, 1889, published in Jaffé (1965, Vol. II, pp. 343-347); see also Uzawa (1960)). It is in this context, and for these
} 
the first edition of the Eléments Walras feels entitled to state that, in each case, the dynamic process "certainly" converges to a stationary solution, which also coincides with the "theoretical" solution of the corresponding equilibrium model. Yet, in a private letter written in 1884, Wicksteed develops a counter-example which forces Walras to recognize that, at least in one case, his alleged convergence "proof" is false ${ }^{10}$. As a consequence, Walras is unwillingly led to mitigate his initial claims about the convergence of the tâtonnement process, by replacing the expression "certain convergence" of the first edition with the less compromising expression "probable convergence" in all the subsequent editions of the Eléments (Walras, 1988, pp. 195, 326, 328, 2-4; p. 698, 3-4).

But the alleged and never proved convergence of the dynamic process to a stationary solution is not the only questionable statement made by Walras about the properties of the tâtonnement construct: as a matter of fact, also his reiterated claim that the "practical" solution identically coincides with the "theoretical" one is not beyond dispute.

Walras is fully aware of the relevance of this claim for his own theory: for, since the "theoretical" solution of any equilibrium model is almost never computable, the practical significance of any such solution, hence the empirical content of the model concerned and, ultimately, of the entire Walrasian theory, come to depend, according to Walras, on the competitive market mechanism being capable, in each concrete case, of automatically driving the economy under question to an equilibrium state that coincides with the "theoretical" solution. Walras is also aware that one necessary, though certainly not sufficient, condition for the claim to hold true is that, during the tâtonnement process, the data of the model should not change: the assumption of data invariance over the entire adjustment process becomes therefore one of the distinguishing features of the Walrasian tâtonnement construct.

This is also the reason why Walras consistently refrains from using the word "dynamics" or any of its derivatives to qualify what, to modern eyes, would undoubtedly appear as a dynamical process. The fact is that, for Walras, "dynamics" is that part of economic theory which has to do with the effects of changes in the data, while "statics" is that part of economic theory which studies the properties of an equilibrium state (or, what is the same, the properties of a "theoretical" solution), given a certain set of data and

reasons, that Walras develops that peculiar iterative method for solving systems of equations, resembling the Gauss-Siedel algorithm, on which we dwelled before.

${ }^{10}$ Wicksteed's letter and Walras's reply are published in Jaffé (1965, Vol. II, pp. 16-18 and 24-26). 
independently of the process through which the equilibrium (or the solution) comes to be established (Walras, 1988, p. 146; p. 308, 2-3; pp. 107, 309, 351, $377,430,447,4)$. Now, since, by assumption, the data must remain unchanged during the tâtonnement process, the tâtonnement itself cannot be regarded as belonging to the sphere of "dynamics": rather, it should be viewed as a sort of appendix to "statics", since in any specific case the data of the tâtonnement are the same as the data of the corresponding "statical" model.

By coming across Bertrand's critical review (Bertrand, 1883, pp. 199-202) of his Théorie mathématique de la richesse sociale, a collection of essays including his first four mémoires (Walras, 1883), and by perusing, a few years later, Edgeworth's critical remarks specifically directed at his theory of the tâtonnement (Edgeworth, 1889, p. 268, and 1891, p. 370), Walras undoubtedly realizes that there exist legitimate interpretations of "statics" and "dynamics" which significantly differ from his own or, what is the same, from Bortkiewicz's (1890, pp. 358-359), who, in his reply to Edgeworth's original attack, simply voices Walras's own ideas; and probably he also realizes that the entire tâtonnement construct is not free from logical, epistemological, as well as analytical difficulties. Yet, apart from an explicit recognition that "ces mots statique et dynamique sont dangereux"11, this awareness does not induce Walras to alter either the formal structure of his theory or his conceptual apparatus; what really changes over the years is the interpretation of the tâtonnement process, in a way that we now intend to elucidate.

As already mentioned, the assumption of data invariance during the adjustment process is a fundamental and invariant pillar of Walras's theory of the tâtonnement over all his active scientific life: no change takes place in this respect from the publication of the first mémoire (1874) to the appearance of the fourth edition of the Eléments (1900). What instead dramatically changes over that time span is Walras's understanding of the constraints that such assumption imposes upon the adjustment processes that the theorist is allowed to contemplate and use for the purposes of the analysis. As a matter of fact, at the beginning of his scientific itinerary Walras is convinced that the tâtonnement construct ought to be so devised as to realistically describe how an equilibrium state comes to be established through an adjustment process taking place in "real" time, that is, over a time

\footnotetext{
${ }^{11}$ This statement can be found in a mémoire attached to a letter that Walras sends to Pareto in 1895 (Jaffé, 1965, vol. II, p. 630). A draft of the mémoire, however, had probably been written a few years before, at the end of the controversy between Edgeworth and Bortkiewicz (Edgeworth, 1891).
} 
set which is the same as that over which the economy concerned is supposed to evolve; moreover, the adjustment process ought to be such that not only in equilibrium, but also out of equilibrium, the individual participants in the economy are allowed to carry out observable behavior, which in turn may affect the evolution of the economy in an essential way. That this is the preanalytic vision of the tâtonnement process guiding Walras in his initial discussion of this construct at the very start of his research activity can be easily inferred from the celebrated informal illustrations of the functioning of a corn market and a security market that are respectively placed before the formal expositions of the exchange equilibrium model in the 1874 mémoire (Walras, 1874, pp. 31-32) and in the first installment of the first edition of the Eléments (Walras, 1988, pp. 71-72) ${ }^{12}$. Moreover, the formal discussion of the tâtonnement process in production, as developed in the second installment of the first edition of the Eléments (1877), as well as in the second (1889) and third (1896) editions of the same book, cannot but confirm that, at least in the case of production, Walras originally conceives and formally represents the tâtonnement process in a very realistic way, as an observable disequilibrium process in "real" time; such conception will then persist, with only minor modifications leaving the essential aspects unchanged, for more than twenty years ${ }^{13}$.

Yet, this realistic conception of the tâtonnement process is inconsistent with Walras's own premises and assumptions: in the first place, Walras is unable to provide any detailed theory of observable disequilibrium behavior which is compatible with the theory of individual choice underlying his version of GET, so that it proves impossible, within the Walrasian framework, to theoretically describe, let alone predict, the path followed by the economy under a hypothetical process of adjustment allowing for observable disequilibrium behavior; in the second place, even granting, for the discussion's sake, that any such observable disequilibrium theory could somehow be concocted, the occurrence of observable disequilibrium behavior would in general disrupt the assumption of data invariance over the tâtonnement process: only few special cases, concerning artificially

12 As regards the latter illustration, in order to appreciate Walras's original viewpoint as expressed in 1874, one should disregard the short sentences inserted here and there into the text since the second edition of the Eléments, for the aim of such sentences is precisely to change the interpretation of the tâtonnement process in a less realistic direction (see footnote 14 below).

${ }^{13}$ See Walras (1988, pp. 308, 310-330, 1 and 2-3). Since in this part of the Eléments the texts of the various editions are strictly interwoven, the various versions of the tâtonnement in production can only be identified by means of a careful perusal, almost line by line, of the relevant pages. 
constructed economies, could escape this fate.

After Bertrand's critique, which is specifically directed at the exchange model, Walras realizes that his original realistic interpretation of the tâtonnement in exchange must be abandoned: hence, since the second edition of the Eléments, he explicitly introduces a "no trade out of equilibrium" assumption which, by ruling out all sorts of observable disequilibrium behavior in the exchange model, turns the corresponding tâtonnement process into a purely virtual process, where nothing observable can occur ${ }^{14}$. Such virtual process evolves over a "logical" time entirely disconnected from the "real" time over which the economy is supposed to evolve. Hence, since it takes just one instant of "real" time for the adjustment process to carry its effects through, the equilibrium state, granting that it is eventually reached, must be imagined as "instantaneously" arrived at, as far as the "real" time of the economy is concerned (Walras, 1885, p. 312, fn. 1).

As to the production and capital formation models discussed in the various editions of the Eléments, however, a sort of generalized "no trade out of equilibrium" assumption is only introduced in the fourth edition of the Eléments, published in 1900, when Walras eventually resolves to adopt the so-called "hypothèse des bons": according to this assumption, no trader (consumer, producer, or owner of the factors of production) is allowed to carry out any actual transaction until an equilibrium is arrived at; until then, all traders can only exchange "bons", that is, conditional claims, which are not effective whenever the economy is out of equilibrium (Walras, 1988, pp. $309,377,447,4)$. With the adoption of the "hypothèse des bons", all sorts of tâtonnement processes, not only in exchange, but also in production, are eventually turned into purely virtual processes, taking place in a "logical" time which is disconnected from the "real" time of the economy; hence, since the fourth edition of the Eléments, the last published in Walras's lifetime, in all the equilibrium models the equilibrium state, granting that it is actually reached, must be supposed to be "instantaneously" arrived at, as far as the "real" time of the economy is concerned.

It is not difficult, at this point, to explain why Walras so strenuously resists the adoption of the "no trade out of equilibrium" assumption and, especially, of its generalization, the "hypothèse des bons", which is in effect introduced more than a quarter of a century after the initial exposition of the Walrasian

\footnotetext{
${ }^{14}$ See the few sentences to this effect added to the security illustration preceding the formal exposition of the theory of exchange in the Eléments (Walras, 1988, pp. 71-72, 2-4). A few years before a "no trade out of equilibrium" assumption had already been introduced in Walras $(1885$, p. 312 , fn. 1). A similar statement can also be found in Walras's mémoire mentioned in footnote 11 above (see Jaffé, 1965, vol. II, p. 630).
} 
version of GET. By turning the equilibration process into a purely virtual process in "logical" time, and consequently by revealing the "instantaneous" character (in "real" time) of the equilibrium concept employed by the theory, the "no trade out of equilibrium" assumption and, a fortiori, the "hypothèse des bons" deprive the tâtonnement construct of most of its realistic flavor. For Walras, as we have seen, the essential purpose of the tâtonnement would be to show how the competitive market mechanism approaches and discovers, by trial and error, the "practical" solution of a given model; this would confer an empirical content first of all to the "practical" solution itself, and then, assuming identity between "practical" and "theoretical" solution, to the latter as well. But it is really difficult to accept that an "instantaneous" process, over which nothing observable can actually occur, can be taken to mimic the functioning of real-world markets. So that, in the end, Walras's elaborate construction, based on the distinction between "theoretical" and "practical" solution, on the one hand, and the connection between the two solutions via the tâtonnement construct, on the other, proves inadequate to satisfy its stated purpose.

\section{Pareto's Perspective}

As is well-known, Pareto's views about the meaning of the equilibrium concept and, more generally, about the scope and significance of GET undergo deep changes over the period ranging from the appearance of his first comprehensive economic treatise, the Cours d'économie politique, published in two volumes in 1896 and 1897, respectively, and the drafting of his more mature and innovative book in theoretical economics, first published in Italian in 1906, under the title Manuale di economia politica, and then again in 1909, in a greatly revised French edition, under the title Manuel d'économie politique $e^{15}$.

The evolution of Pareto's ideas over the turn of the century is partly due to his pursuing, sometimes unconsciously, two different aims: in the first place, Pareto strives to detach himself from the influence of Walras's original conception of GET, which in effect can be strongly felt in the Cours, the most explicitly Walrasian of all Pareto's writings in theoretical economics, but becomes much weaker in the Manuale, and even more so in the Manuel;

\footnotetext{
${ }^{15}$ Quite recently a critical edition of the Manuale (Pareto, 1906) has been published, which also contains the Italian translation of all the passages appearing in the Manuel, but not in the Manuale, as well as the entire mathematical appendix of the Manuel, which significantly differs from that of the Manuale.
} 
in the second place, Pareto also engages in a struggle of escape from the shackles of his own strictly positivistic and empiricist creed, which, after powerfully affecting his own research activity and theoretical conception in the 1890s, apparently loses some of its strength in the first decade of the twentieth century.

The general evolution of Pareto's theoretical and methodological stance in the crucial period going from the publication of the Cours to the appearance of the Manuel cannot but influence also his views concerning Walras's peculiar conception of the meaning and role of the solution concept in general equilibrium models. This is what we are going to discuss in the following subsection.

3.1. Pareto on Walras's twofold solution concept. - At the origin of the different positions taken by Walras and Pareto on the interpretation of the solution concept in GET there are their divergent attitudes towards the significance of the tâtonnement construct. As we have seen, in fact, in all the many editions of the Eléments Walras devotes much effort and a huge number of pages to the discussion of the tâtonnement processes associated with his equilibrium models. Nothing similar can be said of Pareto: for, after downsizing the discussion of the tâtonnement construct to a few lines in the Cours, he completely forgets the very existence of that construct in both the Manuale and the Manuel. As a consequence, barring one single exception, to which we shall come back later, the very idea of a "practical" solution, playing such a central role in Walras's theoretical system, simply disappears from Pareto's reflections and writings.

In the Cours, where, as already recalled, Pareto is still under the spell of Walras's conception of GET, the tâtonnement construct, nowhere mentioned under that name, is briefly discussed in three different places, where Pareto summarizes the equilibrium equations underlying Walras's original models of exchange, production, and capital formation, respectively. In particular, with reference to the exchange model, Pareto's discussion of the dynamical adjustment process boils down to the following few lines:

$\mathrm{M}^{\mathrm{r}}$ Walras a fait voir que le marchandage qui s'établit avec la libre concurrence est le moyen de résoudre par tentatives les équations de l'échange. $\mathrm{M}^{\mathrm{r}}$ Edgeworth a objecté que ce n'était là qu'un moyen. Il a raison; mais le moyen indiqué par $\mathrm{M}^{\mathrm{r}}$ Walras est bien celui qui représente la partie principale du phénomène économique. (Pareto, 1896, p. 25)

With the above statements Pareto marginally enters the already mentioned controversy between Edgeworth and Bortkiewicz about the significance of 
Walras's theory of the tâtonnement. However, in 1896, when Pareto eventually enters the arena, the controversy has already been over for a long time $^{16}$. In the Cours Pareto naturally sides with Walras and Bortkiewicz, but his defense of the tâtonnement construct is weak and weary: for he simply repeats, almost word by word, Bortkiewicz's argument, which had evidently become the official line of defense of the small Walrasian circle.

With reference to the production model, Pareto (1896, p. 47) concisely describes, in a purely informal way, Walras's assumptions concerning the adjustment process in production. Finally, with reference to the model of capital formation, after informally summarizing in a few lines Walras's labored description of the relevant tâtonnement process, Pareto appends the following footnote to the text:

Il faudrait démontrer que, par ces divers ajustements, on se rapproche toujours plus de l'équilibre. [...] Nous ne développerons pas cette démonstration, qui serait inutile aux personnes qui ignorent les mathématiques, et qui sera trouvée facilement par les personnes connaissant la théorie générale des équations. (Pareto, 1896, p. 61, fn. 2)

As we have seen above, however, it is all but easy to prove the convergence to equilibrium of the tâtonnement process associated with the model of capital formation, as Pareto ought very well to have known since, unlike Walras, he is perfectly familiar with the theory of dynamic equations: indeed, should one strictly keep to Walras's original formulation of the tâtonnement process associated with the capital formation model, as Pareto apparently intends to suggest in the text to which the above footnote is appended, the proof would be altogether impossible, since that formulation is inconsistent. Hence, the arguments produced by Pareto for omitting to prove the alleged convergence property of the Walrasian tatonnement process are hardly credible. One might perhaps think that this omission be due to the introductory text-book character of the Cours, which would make the use of some relatively difficult mathematics inappropriate (all mathematical formulae are in effect confined to footnotes). But why then does Pareto completely skip this topic in the appendices of both the Manuale and the Manuel, which are specifically devoted to the examination of thorny mathematical issues? Why does Pareto suppress any reference, even an indirect one, to the tâtonnement, as soon as he succeeds in freeing himself from the cumbersome Walrasian legacy, as he is eventually able to do in the Manuale and the Manuel?

\footnotetext{
${ }^{16}$ Many years later Edgeworth (1925, Vol. II, p. 311) will briefly come back to the same issue, reiterating his ancient criticism.
} 
To answer these questions becomes necessarily a speculative exercise: for, since we cannot accept Pareto's own justifications for his modeling choices or omissions, we are forced to propose an alternative reading of his unfavorable attitude, growing clearer and clearer as time elapses, towards the tâtonnement construct. The first explanation of Pareto's substantial neglect of the Walrasian construct might be exactly the opposite of what he seems to suggest in the Cours: precisely, Pareto would not even try to formalize Walras's tâtonnement process by means of a system of functional (difference or differential) equations, let alone to prove any of its alleged properties, not because such formalization or proof would be too easy or even trivial, but rather because he perfectly knows, being well acquainted with the use of differential equations in rational mechanics, that any such formalization or proof would be exceedingly difficult or even impossible, under Walras's assumptions.

Apart from these analytical difficulties, however, there almost certainly exists also a conceptual obstacle which keeps Pareto from endorsing Walras's approach to the analysis of the equilibration processes. As we have seen above, Walras's tâtonnement construct occupies a very peculiar, half-way position in the Walrasian conceptual system: for, while any proper formalization of the construct would turn the tâtonnement process into an ordinary dynamical process (in the modern sense of the word), Walras tends instead to view it as an appendix to the "statical" part of his theory, due to the underlying assumption of data invariance, which is, in his view, the hallmark of "statics". The tâtonnement construct, therefore, might be regarded as Walras's original attempt at dynamizing (in the modern sense of the word) the equilibrium concept, without calling into question, however, the "statical" nature of the latter. But, as already explained, contrary to Walras's expectations, this attempt at dynamizing the "statical" equilibrium concept is either theoretically inconsistent or empirically irrelevant.

This dilemma, whose very existence Walras tries to deny till the end of his life, is almost certainly perceived by Pareto from the beginning of his scientific career. Starting from his superior knowledge of classical mechanics, Pareto immediately realizes that the static equilibrium notion, as employed in GET, is essentially different from the static equilibrium notion of classical mechanics (of course, we are referring to methodological and analytical, rather than substantive, differences, since the latter would certainly be unsurprising). In particular, while in mechanics a static equilibrium is itself defined by a system of dynamic (that is, functional) equations, so that a smooth transition from statics (or equilibrium analysis) to dynamics is always possible, in economics, instead, a static equilibrium, in 
the sense of Walras's "theoretical" solution, is essentially defined by a system of ordinary, rather than functional, equations, so that no easy transition from statics (or equilibrium analysis) to dynamics is available in this case, as the disappointing outcome of the Walrasian tâtonnement story amply testifies.

Pareto's early awareness of the existence of this sort of difficulties, if not of their possible solution, is clearly witnessed by the following passage:

En mécanique, le principe de d'Alembert nous permet d'étudier, d'une manière complète, l'état dynamique d'un système. Nous ne faisons encore, en Economie politique, qu'entrevoir un principe analogue. En science sociale, cette vague lueur même fait défaut. Dans la première comme dans la seconde de ces sciences, nous sommes obligés de substituer à la considération de l'équilibre dynamique la considération d'une série d'équilibres statiques.

(Pareto, 1897, pp. 9-10)

In the fifteen years following the publication of the Cours Pareto tries hard to discover an economic analogue of the so-called d'Alembert principle in classical mechanics, an analogue which, if discovered, would allow the economist to smoothly switch from economic statics to economic dynamics, and viceversa, as the d'Alembert principle allows the physicist to do in classical mechanics. But his quest proves completely unsuccessful and is eventually abandoned as a dangerous detour ${ }^{17}$.

This negative outcome, on the other hand, could have been easily predicted, since it is simply due to the peculiar nature of economic equilibrium, as employed in GET, which is not amenable to the kind of analysis characteristic of classical mechanics. As Pareto already perceives in writing the Cours, an economic equilibrium, unlike a mechanical one, is an instantaneous equilibrium, supposedly describing the state of economy at a specified instant of time. Supposing time to be interpreted as a discrete variable, so that the economy evolves over an infinite sequence of unit time periods or dates, any such economic equilibrium must be supposed to be instantaneously reached at the initial instant of the corresponding date; since the equilibria typically vary over time, the evolution of the economy can only be described by means of a chronologically ordered sequence of such instantaneous equilibria, which typically differ from one another. This view of both the concept of economic equilibrium and the method that economic theory must employ to describe the evolution of the economy over time is also expressed by Pareto by means of a well-known metaphor, which is developed in the paragraph immediately following the passage of the Cours

\footnotetext{
${ }^{17}$ This aspect of Pareto's research program is discussed in detail in Donzelli (1997).
} 
quoted above:

Pour donner une idée assez grossière, mais expressive de la chose, supposons qu'un homme qui est dans un traîneau, glisse sur une pente. Un autre homme descend à pied la même pente, en s'arrêtant à chaque pas. Les deux hommes partent en même temps du sommet, voyagent constamment en compagnie, et arrivent en même temps en bas de la pente. En gros, leur mouvement est donc à peu près le même. Mais le mouvement de l'homme qui est dans le traîneau, est un mouvement continu, son étude constitue un problème de dynamique. Le mouvement de l'homme descendant à pied, représente une suite de positions successives d'équilibre. Il passe de l'une à l'autre, d'une manière discontinue. C'est précisément une suite semblable de positions d'équilibre que nous pouvons étudier en économie politique. (Pareto, 1987, p. 10, par. 587)

As can be seen from this passage, Pareto's understanding of the reasons why economics (or, better, GET), unlike mechanics, is unable to develop a fully-fledged dynamic theory of the evolution of the systems it studies is still relatively vague, but his intuition of the necessarily instantaneous nature of the economic equilibrium concept is very precise. After many years of unsuccessful attempts at overcoming the limitations of economics, as illustrated in the Cours, the instantaneous interpretation of the notion of economic equilibrium will eventually be reconfirmed by Pareto in both the Manuale $(2006$, pp. 108-109, 240) and the Manuel (1909, pp. 147-148, 337338)), where the pseudo-dynamic method of analysis based on the study of "a sequence of successive equilibrium positions" will also be re-proposed as the characteristic method of economics.

As it should be clear by now, Pareto's instantaneous interpretation of the economic equilibrium concept basically corresponds to the interpretation eventually endorsed by Walras towards the end of his active scientific life, at the time of the publication of the fourth edition of the Eléments (1900). Unlike Walras, however, Pareto arrives at similar conclusions at the very beginning of the most creative period of his life as an economic theorist. This fact may concur to explain Pareto's limited interest in the tâtonnement construct: for when an equilibrium state is regarded as instantaneously reached, the equilibration process must necessarily be interpreted as a purely virtual process in "logical" time; but then the analysis of such a process can contribute very little, or nothing at all, to either supporting the statical equilibrium concept or strengthening the empirical content of equilibrium theory, so that its very raison d'être tends to fade away.

With the substantial disappearance of the tâtonnement construct from Pareto's theoretical framework, also the Walrasian notion of "practical" 
solution, which is intimately connected with the analysis of the equilibration process, goes out of the picture, leaving almost no trace behind. Of the two solution concepts originally introduced and systematically employed by Walras, therefore, only the "theoretical" solution survives. But since it is no longer necessary to distinguish such solution concept from the "practical" one, the very concept of solution becomes superfluous: so that, in the end, what Walras had called the "theoretical" solution of a given model, is simply referred to by Pareto as the equilibrium of that model.

3.2. Pareto on equilibrium determinateness and computability. - The questions of existence, uniqueness and computability, which had been discussed by Walras with reference to his concept of "theoretical" solution, arise once again within Pareto's conceptual framework, with reference to the latter's notion of static equilibrium.

As far as the questions of equilibrium existence and uniqueness are concerned, Pareto's progress with respect to Walras is not really significant. In discussing the issue of equilibrium determinateness, equation-counting is the only criterion that is explicitly mentioned by Pareto not only in the Cours, what is only natural (Pareto, 1896, pp. 24-26, fn. 1, pp. 44-46, fn. 1, pp. 5961 , fn. 1), but also in the much more mature mathematical appendix of the Manuel (Pareto, 1909, p. 665). On the other hand, the reasons explaining such inadequate development of the analysis are the same for Pareto as they were for Walras, so that it is unnecessary to dwell upon them once again.

The issue of equilibrium computability, instead, raises new and interesting problems in Pareto's case, which deserve careful examination. The most relevant aspect, in this regard, is that Pareto's view of the equilibrium computability issue, as well as his interpretation of GET, significantly change over the years, reflecting a corresponding change in some of the methodological premises guiding his theoretical investigations.

Pareto's initial position concerning the empirical content and predictive power of GET, as well as the related question of the computability of economic equilibria, is well expressed by the following passage of the Cours, where he compares economics, or more precisely GET, with other sciences or theoretical systems, such as astronomy or classical mechanics, regarded by most economists and social scientists in Pareto's times as a model for the development of their respective disciplines:

Considérons, en général, certains phénomènes: A, B, C. Nos connaissances sur leur mutuelle dépendance peuvent passer par trois degrés successifs: $(\alpha)$ Nous pouvons seulement savoir que cette dépendance existe $[\ldots]$. ( $\beta$ ) nous pouvons, en outre, avoir une idée des liaisons qui existent entre A, B, C, .. 
[...]. ( $\gamma)$ Enfin, nous pouvons non seulement connaître le sens des ces variations, mais encore en calculer exactement la grandeur. Arrivée à ce point, notre connaissance de l'ensemble des phénomènes $\mathrm{A}, \mathrm{B}, \mathrm{C}, \ldots$ est complète et parfaite.

L'astronomie, pour les mouvements du système solaire, est arrivée à l'état $(\gamma)$. [...] En général, la mécanique nous permet, si les donnés numériques sont suffisantes, d'arriver au degré de connaissance $(\gamma)$, pour un système matériel. A défaut de données numériques, elle nous conduit au moins au degré $(\beta)$.

L'économie politique, avant la découverte des nouvelles théories, était arrêtée au degré $(\alpha)[\ldots]$. Les nouvelles théories ont porté l'économie politique au degré $(\beta)$. Le système complet des équations de l'équilibre économique ne met pas seulement en évidence la mutuelle dépendance des phénomènes, il nous renseigne encore sur le sens des variations de certaines éléments quand on en fait varier d'autres. Il y a plus, ces équations nous font connaître la voie qui, quand la statistique sera en mesure de fournir les données numériques nécessaires, pourra nous permettre de nous élever au niveau $(\gamma)$. (Pareto, 1897, pp. 5-7)

What emerges from the above passage is a conception of scientific knowledge that reflects a strictly positivistic epistemological background and a strongly empiricist methodological approach: according to Pareto, in fact, a certain science or theoretical system allows the scientist to achieve a "complete" and "perfect" knowledge of the class of phenomena falling under its jurisdiction only if it allows the researcher either to "exactly calculate" the magnitudes of the variables involved or to make quantitative predictions of the changes in such variables ensuing from given changes in the "numerical data" of the theory. From this point of view, the "new theories" of "political economy", that is, GET, represent an undisputable progress with respect to the older theories, even if they do not yet allow the scientist to reach a "complete" and "perfect" knowledge of the economic phenomena. This limitation, however, is essentially due to the lack of the "necessary numerical data". As soon as statistics fills this gap, general equilibrium theory, not unlike mechanics, can aspire at providing quantitative predictions of the values of the relevant (presumably aggregate) economic variables, thereby reaching the level of "complete" and "perfect" knowledge.

The last sentence in the above passage can be read as the proposal of a true and proper research program aiming at transforming GET, with the help of statistics and econometrics, into a machinery for quantitative predictions. Now, as is well-known, Pareto makes great progress over the years in the development of statistics and its application to the social sciences. Yet, as far as GET is concerned, no single part of the research program outlined in the Cours is in effect carried out. On the contrary, both in the Manuale and, in 
French translation, in the Manuel, we can find a well-known passage, built upon a rightly celebrated illustration, which provides an entirely different and almost opposite interpretation of GET and its possible uses:

Les conditions que nous avons énumérées pour l'équilibre économique nous donnent une notion générale de cet équilibre. Pour savoir [...] ce que c'était que l'équilibre économique, nous avons dû rechercher comment il était déterminé. Remarquons, d'ailleurs, que cette détermination n'a nullement pour but d'arriver à un calcul numérique des prix. Faisons l'hypothèse la plus favorable à un tel calcul; supposons que nous ayons triomphé de toutes les difficultés pour arriver à connaître les données du problème, et que nous connaissions les ophélimités de toutes les marchandises pour chaque individu, toutes les circonstances de la production des marchandises, etc. C'est là déjà une hypothèse absurde, et pourtant elle ne nous donne pas encore la possibilité pratique de résoudre ce problème. Nous avons vu que dans le cas de 100 individus et de 700 marchandises il y aurait 70.699 conditions (en réalité un grand nombre de circonstances, que nous avons jusqu'ici négligées, augmenteraient encore ce nombre); nous aurons donc à résoudre un système de 70.699 équations. Cela dépasse pratiquement la puissance de l'analyse algébrique, et cela la dépasserait encore davantage si l'on prenait en considération le nombre fabuleux d'équations que donnerait une population de quarante millions d'individus, et quelques milliers de marchandises. Dans ce cas les rôles seraient changés: et ce ne seraient plus les mathématiques qui viendraient en aide à l'économie politique, mais l'économie politique qui viendrait en aide aux mathématiques. En d'autres termes, si on pouvait vraiment connaître toutes ces équations, le seul moyen accessible aux forces humaines pour les résoudre, ce serait d'observer la solution pratique que donne le marché. (Pareto, 1909, pp. 233-234; italics added)

This passage is reminiscent of similar or related statements due to both Cournot and Walras. As to Cournot, the following passage, appearing in one of the few chapters of the Recherches devoted to the discussion of an "entire system" of interrelated markets, certainly represents an important source of inspiration for Pareto, as the italicized part testifies:

Il semble donc que dans la solution complète et rigoureuse des problèmes relatifs à quelques parties du système économique, on ne puisse se dispenser d'embrasser le système tout entier. Or ceci surpasserait les forces de l'analyse mathématique et de nos méthodes pratiques de calcul, quand même toutes les valeurs des constantes pourraient être numériquement assignées. (Cournot, 1838, p. 146)

In this regard, it may be interesting to notice that Cournot's methodological position about the scope and significance of mathematical economics is diversely assessed by the founders of GET. In fact, as we have 
seen above, Walras reproaches Cournot for his alleged propensity towards the employment of "statistical" procedures in view of possible "numerical applications" of the theory of demand. On the contrary, we now see that the last Pareto, dramatically changing his mind in the Manuel with respect to the stance previously taken in the Cours, uses a few words which can certainly be traced back to Cournot, even if the latter is not explicitly mentioned, in order to support a purely qualitative, non-numerical interpretation of $\mathrm{GET}^{18}$.

As to Walras, the first point to stress is that the typically Walrasian expression "solution pratique" is employed by Pareto only in the quoted passage of the Manuel: this expression survives here, in spite of the disappearance from the Manuel of any reference to the tâtonnement process, because Pareto wants to make it absolutely clear that no "calculateur" can possibly replicate what is done in practice by the market. As far as the computability of equilibrium is concerned, Pareto is much sharper than Walras: first of all, while Walras, in the relevant passage of the 1874 mémoire, had been ready to grant that, under the assumption of complete knowledge of the data, the theorist might be able to calculate the "theoretical" solution, Pareto bluntly denies and even ridicules such possibility; in the second place, Pareto simply declares that the assumption of complete knowledge of the data is "absurd" in itself.

But then, given that the numerical computation of the equilibrium values of the economic variables cannot and must not be the task of GET, what is the real significance of this theory? Pareto tentatively answers this question in the paragraph immediately following the passage just quoted:

Mais si les conditions que nous venons d'énumérer ne peuvent pas nous servir pratiquement à des calculs numériques de quantité et de prix, elles sont l'unique moyen connu jusqu'ici pour arriver à une notion de la façon dont varient ces quantités et ces prix, ou, plus exactement, d'une façon générale, pour savoir comment se produit l'équilibre économique. (Pareto, 1909, pp. 234)

This sort of answer is evidently satisfactory for Pareto, for he refers to it many years later, in his Traité de sociologie générale. As a matter of fact, Pareto mentions the above paragraphs of the Manuel at the beginning of a footnote appended to the following sentence in the text of the Traité:

L'économie pure arrive à poser les équations de certaines phénomènes, mais non à résoudre ces équations, au moins en général. (Pareto, 1917-1919, p.

\footnotetext{
${ }^{18}$ As we shall see in the next subsection, the affinity between Cournot's statements about the scope and limitations of general analysis and Pareto's statements in the Manuel about the scope and limitations of GET is underlined by Hayek (1942, pp. 290-291).
} 
1077)

The footnote then proceeds as follows:

Plusieurs économistes sont tombés dans l'erreur de supposer que les théories de l'économie pure pouvaient s'appliquer directement au phénomène concret, et Walras croyait pouvoir réformer ainsi la société [...]. (Pareto, 19171919, p. 1077, fn. 2)

These remarks are interesting since they show that, in the eyes of the last Pareto, the impossibility of computing the equilibrium values of the economic variables is a distinguishing feature of all economic theory. Moreover, he associates in his critique two distinct mistakes which evidently follow, in his opinion, from the same or similar causes: the wrong pretence to numerically solve the economic equilibrium equations, on the one hand, and the fallacious idea that GET can be directly applied to the real world or used to change it, on the other. Finally, it also deserves notice that, according to Pareto, Walras himself is not free from the latter mistake.

3.3. Pareto's final interpretation of GET and Hayek's "explanation of the principle". - As we have seen at the end of the last subsection, in his more mature economic and sociological writings, from the Manuale onwards, Pareto singles out two erroneous readings of pure economic theory or, more specifically, of GET, which are, in his opinion, strictly intertwined: while the first mistaken reading of GET is motivated by a misguided pretence to "quantitative determinism", the second is instead inspired by an attitude which will be frequently referred to as "social constructivism" in the later literature. The link established by the last Pareto between these two regulating principles, which he evidently regards as dangerously misleading methodological rules, at least as far as their application to the social sciences is concerned, is in a sense prophetical, since it anticipates a number of important developments characterizing the social sciences over the entire twentieth century.

As regards economic theory specifically, the first and foremost instance of a reading of GET which is jointly affected by "quantitative determinism" and "social constructivism", the two questionable regulating principles pinpointed by the last Pareto, is represented by an interpretation of GET put forward in the late 1920s and early 1930s, during the second stage of the so-called Socialist Calculation Debate ${ }^{19}$, by a group of young socialist economists, well

\footnotetext{
${ }^{19}$ A detailed critical reconstruction of the various stages of the Socialist Calculation Debate, and specifically of the interpretations proposed, and the uses made, of GET by the
} 
conversant with the contemporary developments in general competitive equilibrium theory ${ }^{20}$ : according to the position taken by these socialist economists, a position which might be referred to as the "first socialist interpretation of GET", the economic calculation and allocation problems arising in a centrally planned economy without markets of any sort could be solved by directly computing the numerical solution of a system of simultaneous equations defining the static equilibrium conditions of a suitably specified general competitive equilibrium model of Walrasian derivation, supposedly describing the structure of the economy concerned at a given date.

This sort of interpretation of GET cannot but attract the attention of Hayek, who has been working since the late 1920s on the meaning of the equilibrium concept in economic theory and the significance of the general equilibrium approach for the analysis of dynamic phenomena and processes in competitive economies. In the mid-1930s Hayek eventually enters the Socialist Calculation Debate, which is then well under way, with the explicit purpose of criticizing those analyses, underlying the "first socialist interpretation of GET", that are

directed to show that, on the assumption of a complete knowledge of all relevant data, the values and the quantities of the different commodities to be produced might be determined by the application of the apparatus by which theoretical economics explains the formation of prices and the direction of production in a competitive system. (Hayek, 1935, p. 152)

Against this claim Hayek initially raises the same objections as Pareto had already raised in the passage of the Manuel quoted above: namely, he objects that, due to the peculiar nature of the data of GET, which are individual, subjective, and dispersed among millions of different people, the very "assumption of a complete knowledge of all relevant data" is an "absurd hypothesis" in itself; further, he objects that, even granting, for the discussion's sake, that the Central Planning Authority could somehow acquire that "complete knowledge of all relevant data" that is needed to write down a general equilibrium model which can, in principle, be computed, the task of actually computing a numerical solution and working out the concrete decisions that it implies would be "a task which, with any of the means known at present [1935], could not be carried out in a lifetime" (Hayek, 1935, p. 156). Yet, against the "first socialist interpretation of GET" Hayek

economists taking part in the Debate on both sides of the divide (namely, on both the "socialist" and the "market" side), can be found in Donzelli (1993).

${ }^{20} \mathrm{See}$, in particular, Taylor (1929), Roper (1929), and Dickinson (1933). 
also moves two further criticisms that, though connected with those of Paretian derivation, are also partly new and will become, in the course of time, a distinctive trait of Hayek's approach: in the first place, he underlines that, while the collection of the relevant data and the computation of the numerical equilibrium values of the unknown variables, if at all possible, would anyhow necessarily require a huge amount of time, in all real economies the data "change from moment to moment", so that in the end what might be collected and conveyed to the authority in charge of the computation would never correspond to the actual situation of the economy concerned; in the second place, he points out that the insurmountable difficulty of collecting all the relevant data and concentrating all the knowledge dispersed among the members of the economy into one single mind or entity is not only due to practical reasons, but also depends on the logical impossibility of inducing the individuals participating in the economy to elicit their "tacit" knowledge, that is, that fundamental part of all individual knowledge that is not consciously possessed even by those who do make use of it (Hayek, 1935, p. 155).

Given the similarity between most of the objections advanced by Hayek in his 1935 essay against the numerical computability of an economic equilibrium and the remarks on the same issue originally made by Pareto in the Manuel and later writings, it is by no means surprising that Hayek, on coming back to the Socialist Calculation Debate after a few years, should open his 1940 contribution to that Debate with the unabridged quotation of the long passage drawn from Pareto's Manuel that we have reproduced above: such passage, in fact, is of paramount importance for Hayek, because it confirms that the "first socialist interpretation of GET" runs foul of the reading of GET suggested, at least in his most mature works, by one of the very founders and most respected interpreters of the approach (Hayek, 1940, pp. 181-182).

Yet Hayek's 1940 paper is not so much concerned with the "the first socialist interpretation of GET", but rather with the critical discussion of a new proposal, also known as the "competitive solution", advanced in the second half of the 1930s by a group of socialist economists, later called the "market socialists", whose best-known representatives are Lange, Lerner, and Dickinson" ${ }^{21}$. The aim of the "market socialists" is to solve the calculation and allocation problems arising in a partially decentralized socialist economy with some competitive market traits. Their proposal, resting on an apparently realistic reinterpretation of GET that might be called the "second socialist

\footnotetext{
${ }^{21}$ See, in particular, Lange (1936 and 1937), Lerner (1937 and 1938), and Dickinson (1939).
} 
interpretation of GET", lies at the center of the third and last stage of the Socialist Calculation Debate. As their socialist predecessors in the preceding stage of the Debate, also the "market socialists" use a simple general equilibrium model to describe the economy they are concerned with. But, unlike their predecessors, they do not claim that an equilibrium of the economy can be directly computed by numerically solving the system of ordinary equations underlying the equilibrium model concerned; rather, they claim that such an equilibrium can be approached by trial and error, that is, by means of an iterative adjustment process which is nothing other than a "socialist" reinterpretation of the Walrasian tâtonnement, duly modified to take into account the partially decentralized socialist character of the economy.

It should be recalled, at this point, that Walras, while starting from a highly realistic interpretation of the tâtonnement as an observable disequilibrium process in "real" time, had been forced to adopt a less and less "realistic" interpretation of the same construct in the hope of counteracting the logical and analytical difficulties arising from his original account: as we have seen before, with the adoption of the "hypothèse des bons" in the fourth edition of the Eléments, the Walrasian tâtonnement had eventually become an utterly unrealistic construct, where a purely virtual process, evolving in a sort of "logical" time, consumes no amount of "real" time to carry its effects through. But, of course, when Lange, the most analytically oriented of the "market socialists", resurrects the Walrasian tâtonnement in the second half of the 1930s, he is forced, for obvious reasons, to adopt a much more concrete interpretation of that construct: for, after all, the revised tâtonnement is to become the pillar of a proposal of social and economic reform, aimed at reorganizing the actual functioning of the economy along "market socialist" lines, in the spirit of "social constructivism". Hence Lange, unlike the last Walras, has to envisage his "socialist" tâtonnement as a process taking place in "real" time. Moreover, he has also to fill an apparent gap in Walras's original story: for, while Walras had deliberately avoided specifying in detail who should be in charge of changing the prices (as well as the quantities produced, in the production models) in the course of the adjustment process, Lange cannot of course afford dodging this question. Being forced to assign the task of adjusting the state variables of the equilibration process to a welldefined entity, Lange chooses to assign it to the Central Planning Board of his "market socialist" economy; this Board, therefore, is bound to become the ancestor of a much more ethereal character playing a central role in all the later formalized versions of the tâtonnement story, namely, the so-called "Walrasian auctioneer". 
In conclusion, barring Walras's initial attempts at dressing up his own tâtonnement construct in realistic clothes, Lange's "socialist" version of the tâtonnement paradoxically represents the most elaborate attempt at providing a fully-fledged interpretation of the competitive adjustment process as a "real" process taking place in "real" time in a supposedly "real" economy (albeit only a "market socialist" one). In so doing, however, Lange unwillingly lays bare all the difficulties inherent in that construct, difficulties which had already emerged in the realistic versions of the tâtonnement initially put forward by Walras and could only be concealed by his final adoption of the "hypothèse des bons" and the consequent virtualization of the entire process.

It is then relatively easy for Hayek, in his 1940 contribution, to disclose the inner contradictions of the "second socialist interpretation of GET" and, especially, of the associated "socialist" version of the tâtonnement story: for all such contradictions are ultimately related to the pretence of constructing an observable disequilibrium process in "real" time, without renouncing, at the same time, the traditional assumption of parametric rationality which characterizes the agents' maximizing behavior in all general equilibrium models of Walrasian derivation; and this dilemma, as can be seen, is essentially the same as the one in which Walras himself had been caught when he had tried to develop a realistic version of the tâtonnement construct providing a link between the "theoretical" and the "practical" solution of each of his equilibrium models. In essence, and with specific reference to the kind of economy envisaged by the "market socialists", Lange's "socialist" version of the tâtonnement can be blamed, according to Hayek, for the following reasons: first, it is unable to explain why the agents (and especially the production managers of the state-owned industries) should "stupidly" behave as price-takers, while knowing that the prices would be changed by the Central Planning Board whenever the economy is out of equilibrium; second, it is unable to account for the agents' disequilibrium behavior, even if, with the proposed method of price fixing and changing, disequilibrium should be expected to be the norm in any such "market socialist" economy; third, in the hope to make the equilibrium position determinate, it is forced to inconsistently assume away, once again in the wake of the early Walras, all changes in the data, even those changes that would necessarily follow from the agents' out-of-equilibrium behavior ${ }^{22}$.

Having disposed of both the "first" and the "second socialist interpretation of GET", and having perceived that misguided views about the meaning and possible uses of the notion of economic equilibrium abound, even among

${ }^{22}$ See Hayek (1940, pp. 188, 193-194, 197-198). 
well-trained general equilibrium theorists, at the beginning of the 1940s Hayek feels obliged to explain his own position about the significance of the equilibrium approach in economics: in his intentions, of course, the proposed interpretation of GET should be consistent with the views expressed by the founders of the approach and, at the same time, should be free from the strictures that can be passed upon the "constructivist" readings of GET suggested by the "market socialists" and other economic planners during the Socialist Calculation Debate.

As it turns out, Hayek's suggested interpretation is nothing but a revised version of the reading of GET put forward by the last Pareto in the passages of the Manuel quoted at the end of the previous subsection. Yet, Hayek is also interested in showing that the sort of explanations we can expect from GET should be viewed as a particular instance of a larger class of explanations, recurring in the theoretical systems of the social sciences for reasons connected with the peculiar subject-matter of those sciences. All this is explained in the following passage, drawn from the first part of a long methodological essay, in three parts, written by Hayek in the period 19421944:

The number of separate variables which in any particular social phenomenon will determine the result of a given change will as a rule be far too large for any human mind to master and manipulate them effectively. In consequence our knowledge of the principle by which these phenomena are produced will rarely if ever enable us to predict the precise result of any concrete situation. While we can explain the principle on which certain phenomena are produced and can from this knowledge exclude the possibility of certain results, e.g. of certain events occurring together, our knowledge will in a sense be only negative, i.e. it will merely enable us to preclude certain results but not enable us to narrow the range of possibilities sufficiently so that only one remains.

To these general remarks concerning the distinctive problems of explanation and prediction in the social sciences, Hayek adds the following sentences, which are directly relevant to the issue with which we are specifically concerned here:

The distinction between an explanation merely of the principle on which a phenomenon is produced and an explanation which enables us to predict the precise result is of great importance for the understanding of the theoretical methods of the social sciences. [...] The best illustration in the field of the social sciences is probably the general theory of prices as represented, e.g., by the Walrasian or Paretian systems of equations. These systems show merely the principle of coherence between the prices of the various types of commodities of which the system is composed, but without knowledge of the numerical 
values of all the constants which occur in it and which we never do know, this does not enable us to predict the precise results which any particular change will have. Quite apart from this particular case, a set of equations which shows merely the form of a system of relationships but does not give the values of the constants contained in it, is perhaps the best general illustration of an explanation merely of the principle on which any phenomenon is produced. (Hayek, 1942, pp. 290-291) 23 $^{23}$

This passage, written by Hayek at the end of an important historical controversy, has the merit of clarifying the methodological foundations underlying two alternative interpretations of GET, recurrently advocated by opposing groups of economic theorists, social reformers and policy makers since the beginning of the approach: on the one hand we find theorists like Hayek himself or the last Pareto who, believing that general equilibrium models can only provide "explanations merely of the principle", dismiss any attempt to use GET as a computing device or a policy tool as a dangerous "constructivistic" abuse; on the other hand, we find economists like the supporters of the "first socialist interpretation of GET" or, in a subtler way, the advocates of the "second socialist interpretation" as well, who, believing that general equilibrium models enable the social scientist to "predict the precise result of any concrete situation", encourage the use of GET for computing or policy purposes.

Now, while Hayek's arguments in the Socialist Calculation Debate appear more convincing than those offered by his opponents, and while it can fairly be said that he comes out of the Debate as the undisputed winner, it is by no means clear that Hayek's (or, for that matter, the last Pareto's) interpretation of GET as the source of "explanations merely of the principle" is the only one to survive to the historical controversy. As a matter of fact, before the Debate, the alternative interpretation of GET as the provider of "explanations" or "predictions of the precise result" had already been conspicuously present in the then relatively small general equilibrium community: as we have seen, in fact, after occasionally tempting Walras himself, such interpretation had been explicitly endorsed by no less than the early Pareto. Then, after the Debate, the potentially "deterministic" or "constructivistic" interpretation of GET, instead of dwindling or disappearing, as one might perhaps have expected, has gone on thriving: in particular, it has directly affected the continuously growing and by now huge

${ }^{23}$ In a footnote appended to the passage cited in the text Hayek, with a view to strengthening his position, reproduces once again the passage from Pareto's Manuel, as well as the passage from Cournot's Recherches quoted in subsection 3.2 above. 
literature on the computation of economic equilibria ${ }^{24}$. These historical vicissitudes cannot but mean that, in spite of all methodological caveats put forward by influential theorists, the very structure of GET is such as to foster (or, at the very least, not to discourage) the temptation to read the theory through "deterministic" or "constructivistic" lenses.

\section{Concluding Remarks}

For the founder of GET, Léon Walras, the "theoretical" solution of a general equilibrium model is the mathematical solution of the system of ordinary equations defining its structure: it implicitly defines an equilibrium of the model; the "practical" solution, instead, is the stationary solution of the system of functional equations describing the adjustment process brought about by the competitive market mechanism. According to Walras, for any given model the two solutions should coincide: the theory of the tâtonnement should take care of showing how the adjustment process converges to a "practical" solution, which also coincides with the "theoretical" solution of the model.

Very often, but not invariably, Walras takes for granted that the "theoretical" solution or the equilibrium of a given model exists and is unique. However, even under the most favourable assumption of equilibrium existence and uniqueness, Walras supposes that "in almost all cases" the "theoretical" solution cannot be computed. He assumes, however, that the competitive market mechanism typically drives the adjustment process towards the "practical" solution or, in view of the assumed coincidence between the two solutions, towards the "theoretical" solution as well. In view of this, the "theoretical" solution, even if not directly computable, indirectly acquires an empirical character, which is conferred upon it by the competitive market mechanism underlying the adjustment process.

Since, according to Walras, the empirical content of the theory ultimately depends on the convergence of the adjustment process to the "theoretical" solution, the theory of the tatonnement, which deals precisely with the adjustment process, comes to play a fundamental role in Walras's overall construction. But Walras's theory of the tâtonnement is defective: starting from a highly realistic interpretation of the tâtonnement as an observable disequilibrium process in "real" time, Walras progressively realizes that such an interpretation is inconsistent with the fundamental premises of his theory and, especially, with the assumed coincidence of the "practical" solution with

\footnotetext{
${ }^{24}$ See, e.g., Scarf (1982) and Kehoe (1991).
} 
the "theoretical" one. For this reason, in the fourth edition of the Eléments (1900), Walras eventually resolves to make an assumption, the so-called "hypothèse des bons", which turns the tâtonnement process into a purely virtual process in "logical" time, taking just one instant of "real" time to drive the economy towards an equilibrium state. In this way some of the analytical problems arising in the previous versions of the tâtonnement are made to disappear, but all the realistic flavor surrounding the construct is lost.

This is one of the reasons why Pareto progressively trims down the role of Walras's tâtonnement in his overall system of thought: while paying lipservice to that construct in the Cours (1896-97), he ends up by completely neglecting it in the Manuale (1906) and the Manuel (1909). Together with the tâtonnement, also the notion of "practical" solution disappears from Pareto's theoretical framework, so that Walras's notion of "theoretical" solution, simply referred to as an "equilibrium" by Pareto, is the only one to survive.

The disappearance from the picture of Walras's tâtonnement, however, does not induce Pareto, at least at the beginning of his scientific career, to revise his positivistic attitude towards the empirical character of GET or his optimistic expectations about the predictive power of the theory: on the contrary, in the Cours, he explicitly states that, provided that enough numerical data are collected and made available with the aid of statistics, GET can aspire at making numerical predictions as precise as those of mechanics, astronomy, and the natural sciences in general.

This view, however, is bound to change dramatically over the years: in fact, in both the Manuale and the Manuel, Pareto makes it absolutely clear that, in view of the peculiar nature of the data of GET, the assumption that a complete knowledge of the relevant data of a certain economic model can somehow be acquired by the theorist is an "absurd hypothesis"; moreover, even if a complete knowledge of the data could ever be obtained, the computation of the equilibrium values of the unknown variables would all the same prove impossible, due to the unmanageable complexity of the equation system to be solved.

Pareto's arguments are taken up again and further developed by Hayek in the late 1930s and early 1940s, during the last two stages of the so-called Socialist Calculation Debate: in contrast with the "socialist interpretations of GET" put forward by various groups of socialist economists from the late 1920 s to the end of the 1930s, interpretations which aim at turning GET into a computing device or a tool for implementing social and economic reforms, Hayek reiterates the last Pareto's view of GET as a theoretical system that cannot provide "explanations" or "predictions of the precise result", but can only yield "explanations of the principle on which a phenomenon is 
produced". A cursory glance at the history of GET, however, cannot but confirm that there is no general consensus among theorists and scholars about the possibility or impossibility of using GET for computing equilibria or making numerical predictions of the phenomena falling under its jurisdiction.

\section{REFERENCES}

ANTONELli E., "Léon Walras et sa correspondance avec Augustin Cournot et Stanley Jevons", Econometrica, 1935, 3, pp. 119-27.

Arrow K. J. and HAHN F.H., General Competitive Analysis, San Francisco-Edinburgh: Holden-Day - Oliver and Boyd, 1971

BERTRAND J., "Théorie mathématique de la richesse sociale, par Léon Walras, professeur d'économie politique à l'académie de Lausanne, Lausanne, 1883. Recherches sur les principes mathématiques de la théorie des richesses, par Augustin Cournot, Paris, 1838”, Journal des Savants, septembre, 504-8; as reprinted in BRIDEL (1996, pp. 195-202).

BortKiEwicz L., von, "Review of 'Leon Walras, Eléments d'économie politique pure, ou Théorie de la richesse sociale', $2^{\mathrm{e}}$ édition”, Revue d'économie politique, janvier-février, 1890, 4(1), pp. 80-86; as reprinted in BRIDEL (1996, pp. 355-59).

BRIDEL P., Le chêne et l'architecte. Un siècle de comptes rendus bibliographiques des Eléments d'économie politique pure de Léon Walras, Genève- Paris: Librairie Droz, 1996.

COURNOT A. [1838], Recherches sur les principes mathématiques de la théorie des richesses, Paris: Marcel Rivière \& $C^{\text {ie }}, 1938$.

DiCKINSON H. D., "Price Formation in a Socialist Community", Economic Journal, 1933, 43, pp. 237-50.

—_ Economics of Socialism, Oxford: Oxford University Press, 1939.

DoNZELLI F., "The Influence of the Socialist Calculation Debate on Hayek's View of General Equilibrium Theory", Revue européenne des sciences sociales, 1993, 31, 96, pp. 47-83.

—_ "Pareto's Mechanical Dream”, History of Economic Ideas, 1997, 5(3), pp. 127-78.

_ , "Equilibrium and Tâtonnement in Walras' Eléments", UNIMI - Research Papers in Economics, Business, and Statistics. Economics, Working Paper 5, July 2005. http://services.bepress.com/unimi/economics/art5

Edgeworth F. Y., "The Mathematical Theory of Political Economy, Eléments d'Économie Politique Pure. Par Léon Walras", Nature, 40, No. 1036, September 5,1889, pp. 434-36; as reprinted in BRIDEL (1996, pp. 267-69).

—_, "La théorie mathématique de l'offre et de la demande et le coût de production", Revue d'économie politique, janvier 1891, 5(1), pp. 10-28; as reprinted in BRIDEL (1996, pp. 363 75).

_ _ Papers Relating to Political Economy, 3 vols., Macmillan: London, 1925.

Hayek F. A., von, "The Present State of the Debate", in F. A. von Hayek, ed., Collectivist 
Economic Planning: Critical Studies on the Possibilities of Socialism, London: George Routledge \& Sons, 1935; as reprinted in F. A. von Hayek, Individualism and Economic Order, London: George Routledge \& Sons, 1949, pp. 148-80.

_ , "Socialist Calculation: The Competitive 'Solution"”, Economica, May 1940, n.s., 7, 26, pp. 125-49; as reprinted in F. A. von Hayek, Individualism and Economic Order, London: George Routledge \& Sons, 1949, pp. 181-208.

__ "Scientism and the Study of Society", Economica, August 1942, n.s., 9, 35, pp. 267-91.

JAFFÉ W., Correspondence of Léon Walras and Related Papers, 3 vols., edited by William Jaffé, Amsterdam: North-Holland, 1965.

KeHOE T. J., "Computation and Multiplicity of Equilibria", in W. Hildenbrand and $\mathrm{H}$. Sonnenschein, eds., Handbook of Mathematical Economics, Volume IV, Chapter 38, Amsterdam: North-Holland, 1991, pp. 2049-143.

LANGE O., "On the Economic Theory of Socialism (Part I)", Review of Economic Studies, 1936, 4, pp. 53-71.

_ , "On the Economic Theory of Socialism (Part II)", Review of Economic Studies, 1937, 5, pp. 123-42.

LERNER A., "Statics and Dynamics in Socialist Economics", Economic Journal, 1937, 47, pp. 251-70.

, "Theory and Practice in Socialist Economics", Review of Economic Studies, 1938, 6, pp. $71-75$

PARETo V. [1896], Cours d'économie politique. Tome I, Nouvelle édition par G.-H. Bousquet et G. Busino, Genève: Librairie Droz, 1964.

_ [1897], Cours d'économie politique. Tome II. Nouvelle édition par G.-H. Bousquet et G. Busino, Genève: Librairie Droz, 1964.

_ [1909], Manuel d'économie politique, Genève: Librairie Droz, 1966.

— [1917-1919], Traité de sociologie générale, Genève-Paris: Librairie Droz, 1968.

_- Manuale di economia politica, Edizione critica a cura di A. Montesano, A. Zanni, L. Bruni, Milano: Università Bocconi Editore, 2006.

Roper W. C., The Problem of Pricing in a Socialist State, Cambridge, MA: Harvard University Press, 1929.

SCARF H. E., "The Computation of Equilibrium Prices: An Exposition", in K. J. Arrow and M. D. Intriligator, eds., Handbook of Mathematical Economics, Volume II, Chapter 21, Amsterdam: North-Holland, 1982, pp. 1007-61.

TAYLOR F. M., "The Guidance of Production in a Socialist State", American Economic Review, 1929, 19, pp.1-8.

Uzawa H., "Walras' Tâtonnement in the Theory of Exchange", Review of Economic Studies, 1960, 27, pp. 182-94.

, "Walras's Existence Theorem and Brower's Fixed Point Theorem", Economic Studies Quarterly, 1962, 8, pp. 59-62. 
Walras L., "Principe d'une théorie mathématique de l'échange", Séances et travaux de l'Académie des sciences morales et politiques (Institut de France), Collection, $33^{\mathrm{e}}$ année, nouvelle série, 101, tome I, Paris: Alphonse Picard, janvier 1874, pp. 97-116 ; as reprinted in WALRAS (1993, pp. 27-46).

(1876a), "Equations de l'échange", Bulletin de la Société vaudoise des sciences naturelles, $2^{\mathrm{e}}$ série, 14, no. 76, octobre 1876, pp. 365-94; as reprinted in WALRAS (1993, pp. 53-72).

(1876b), "Equations de la production", Bulletin de la Société vaudoise des sciences naturelles, $2^{\mathrm{e}}$ série, 14 , no. 76, octobre 1876, pp. 395-430; as reprinted in WALRAS (1993, pp. 73-99).

_ ,Equations de la capitalisation", Bulletin de la Société vaudoise des sciences naturelles, $2^{\mathrm{e}}$ série, 15, no. 77, mars 1877; as reprinted in WALRAS (1993, pp. 101-30).

_ [1883], Théorie mathématique de la richesse sociale, as reprinted in WALRAS (1993, pp. 225-78.

__ , "Un économiste inconnu: Hermann-Henri Gossen", Journal des économistes, 4 e série, avril-mai 1885, 30, pp. 68-90; as reprinted in WALRAS (1896, pp. 311-30).

—_ Etudes d'économie sociale: Théorie de la répartition de la richesse sociale, édition comparée, in Auguste et Léon Walras, Euvres économiques complètes, 9, Paris: Economica, 1896.

, Eléments d'économie politique pure ou Théorie de la richesse sociale, édition comparée, in Auguste et Léon Walras, Euvres économiques complètes, 8, Paris: Economica, 1988.

_ Théorie mathématique de la richesse sociale et autres écrits d'économie pure, in Auguste et Léon Walras, EEuvres économiques complètes, 11, Paris: Economica, 1993.

Weintraub E. R., “On the Existence of a Competitive Equilibrium: 1930-1954”, Journal of Economic Literature, 1983, 21, pp. 1-39. 